\title{
HISTORICAL PRESERVATION DISTRICTS AND \\ HOME SALE PRICES: EVIDENCE FROM THE SACRAMENTO HOUSING MARKET ${ }^{1}$
}

\author{
David E. Clark and William E. Herrin ${ }^{*}$
}

\begin{abstract}
During the past two decades, cities have turned increasingly to historic preservation of residential and commercial property as a method to help revive declining metropolitan areas. Sacramento, California, established historical preservation districts in an attempt to protect and maintain older structures while simultaneously increasing their value. Historic preservation, however, imposes strict rules on property owners that make property improvement more expensive than it otherwise would be. This paper uses hedonic price theory on a sample of residential properties in Sacramento to test whether positive externalities resulting from an historic preservation designation outweigh the potential negative impact of a cumbersome set of rules. The findings suggest that an historic preservation designation has a net positive impact on property values in four of the six preservation districts in the sample.
\end{abstract}

\section{INTRODUCTION}

In the late 19th century, the city of San Francisco passed an ordinance that banned laundries from certain neighborhoods. Because the purpose of the law was to keep an undesirable land use out of some residential areas, this first zoning law did not violate the Constitution. Since then, zoning and other land use controls have become an integral part of the U.S. metropolitan landscape. Today, most U.S. metropolitan areas use zoning ordinances in an attempt to mitigate externalities resulting from unfettered land development. In theory, their purpose is to promote public health, safety, and welfare. Delafons (1969) provides a history of zoning and other land use controls while Fischel (1985) discusses their legal foundation. Mills (1979) discusses the use of zoning as a means of controlling externalities.

During the past two decades, land use ordinances have evolved in a different direction in metropolitan areas where historic preservation has become popular. ${ }^{2}$ These metropolitan areas have created historic preservation districts (HPDs) that establish rules by which owners must abide when making property alterations. HPDs are created for numerous reasons. Among these are the desire to generate renewed interest in inner-city residential locations among middle- and upper-middle class families (gentrification) as well as to help preserve a municipality's tax

\footnotetext{
*Associate Professor of Economics, Marquette University, Milwaukee, WI; and Associate Professor of Economics, University of the Pacific, Stockton, CA.
} 
base by encouraging renovation of residential and commercial property. Coffin (1989) studies the impact of HPDs on residential housing prices in Aurora and Elgin, Illinois. His results provide some support for proponents of HPDs as a neighborhood revitalization tool by showing a modest positive impact on prices in Aurora. Garrod et al. (1997) go further. They use contingent valuation methods to determine willingness to pay for renovation and restoration of buildings in Newcastle upon Tyne. Their findings suggest that local residents have strong preferences for such projects and are willing to pay higher local taxes to support neighborhood renovation.

Historic preservation districts began in Sacramento when the Sacramento Preservation Program was formally established with the adoption of Ordinance $3469-4^{\text {th }}$ Series (Chapter 32, City Code) on January 18, 1975. The purpose of the program is to protect and maintain architecturally, historically, and culturally significant structures and areas dating from 1848 through 1920 in what are referred to as Preservation Areas. ${ }^{3}$ The ordinance created the Preservation Board as the public body responsible for the city's preservation efforts. The Board's initial responsibility was the development of the city's Official Register, which identified significant pre-1920 residential buildings. Adoption of the Listed Structures Plan and the Preservation Area Plan followed. ${ }^{4}$

The Board is responsible for reviewing all projects involving relocation, signage, new construction, demolition, and exterior remodeling of buildings within preservation areas. The intent is not to require that new construction be reproductions of older structures, but to ensure that new construction be complementary to the Preservation Area in scale, bulk, height, design, and general character. The current Preservation Area Plan lists detailed standards and criteria designed to meet these preservation goals. The Plan's guidelines regulate the types of exterior building materials and color schemes that can be used when rehabilitation occurs. For example, original, nonimitation materials need to be used where possible, and no more than five muted colors are allowed for exterior paint schemes. The Plan also regulates architectural details such as the style of fences, roofs, chimneys, cornices, porches, garage doors and other accouterments. ${ }^{5}$ Clearly, the creation of these Preservation Areas imposes significant restrictions on exterior alterations.

A further analysis of the intent of the Preservation Board is called for to understand the motivation for these restrictions. The Residential Building Listed Structures Plan states that these standards are necessary because ". . Good rehabilitation decisions and quality workmanship are important to the ultimate visual character of a house. The first and lasting impression of a structure is created by its exterior appearance." ${ }^{6}$ Furthermore, the Plan argues that ". . . improvements ... should restore or retain the original design to the greatest extent 
possible. ${ }^{77}$ It is believed that maintaining the original design as much as possible will increase the values of the properties. "Many well-intentioned homeowners have spent a lot of money on inappropriate (emphasis ours) features when rehabilitating their older homes, with the result that the value of their property was lessened rather than increased. [The] pressure to 'modernize' houses that were built before the turn-of-the- century ... was characterized by excessive use of aluminum windows and asphalt or asbestos shingles. Changes of this type often removed the individuality and charm of neighborhoods and de-characterized and confused the design intent of many houses. ${ }^{.8}$

From a theoretical perspective, the Preservation Board's imposition of restrictions is an attempt to internalize neighborhood externalities that are believed to depress property values. The Board implies there are two sources of these negative externalities. The first and most obvious is the externality created by property deterioration due to lack of proper maintenance and rehabilitation. The second source follows from the Board's implicit hypothesis that any rehabilitation that changes the 'look' of an older structure and hence the 'character' of the neighborhood in which it is located causes a negative externality. It then follows that preservation would mitigate both sources and thus increase property values.

The Listed Structures Plan describes the procedures one must go through before receiving a permit to commence with property alteration. The permit application process is extensive. The Board must be provided with a copy of the site plan that contains, among other things, the location of points of entry and exit of vehicles and the location of existing trees and other landscaping. A copy of architectural drawings, including the height of all sides of all structures and details of any mechanical devices placed on the roof, site photographs, surveyors' records, and a proposed color, materials, and texture palette are also required. The Board also reserves the right to require the applicant to provide any other information it deems necessary. Following receipt of the application, the Board schedules a hearing at which it makes a recommendation to approve, approve with conditions, or disapprove the plan. If approved, the applicant must submit another set of final working drawings and a final landscaping plan to the Preservation Director. The director does one more review, and, if satisfied, directs the Building Department to issue the proper permits.

When considered in light of this application procedure, the Board's argument that preservation will increase property values is less convincing. The Board feels that the lengthy application procedure is necessary to mitigate the second source of negative externalities. But if property owners decide to avoid this costly process and delay maintenance and rehabilitation, externalities from the first source will eventually ensue. Likewise, a cumbersome application procedure may 
deter buyers from purchasing a property in a Preservation Area. In both cases, Preservation Areas may thus lead to lower property values.

One might look at this issue in another way. The Board believes that a positive 'authenticity externality' results when homeowners improve their properties according to the above rules. However, other positive externalities may also exist inside an HPD. Federal tax law, for example, provides for up to a 20 percent reduction in a homeowner's tax liability for improvements done on residences certified as historic and built before 1936. This may provide a stronger incentive to improve inside than elsewhere in the area because of higher expected returns there. It would then be impossible to separate the effects of this upkeep externality' from the authenticity effects. Moreover, if the positive upkeep externality of the preservation policy is strong enough, it could offset a net negative authenticity effect due to the strict rules. Observed increases in property values would then not be the result of preservation, but simply of more general policy that encourages upkeep.

On the other hand, neither the Listed Structures Plan nor the Preservation Area Plan specifically requires homeowners to improve deteriorating property. While tax law may provide necessary incentive, it is not sufficient to guarantee the dominance of the upkeep effect. In light of this, observed property value increases inside an HPD suggest the dominance of one or more positive externalities over the higher cost of improvement due to the strict rules in place there. Alternatively, decreases in values would suggest that the rules overwhelm any benefits from the authenticity and upkeep externalities. ${ }^{10}$

\section{EMPIRICAL MODEL}

\section{A. Theoretical Background}

Hedonic price theory is the basis for the empirical model. Initially developed by Lancaster (1966) and later refined by Rosen (1974) and Freeman (1979), the hedonic model has been used extensively to implicitly value structural characteristics of a house (Kern and Lichtenstein 1987; Linneman 1980); fiscal and regulatory characteristics of a community (Stull and Stull 1991); and a wide range of neighborhood attributes including crime rates (Clark and Cosgrove 1990; Thaler 1979); proximity to employment centers and subcenters (Bender and Hwang 1985; Herrin and Kern 1992); and air quality (Ridker and Henning 1967; Harrison and Rubinfeld 1978).

The theory underlying the hedonic model has been developed and reproduced in detail numerous times and will only be briefly reviewed here. In its 
essence, the single-stage hedonic model views housing as a differentiated bundle of characteristics of both the structure and the neighborhood in which the structure is located. Assuming (1) perfect information about the bundle of attributes embodied in each house; (2) zero transactions costs in market trades of bundles; and (3) a continuous offering of attributes, the market price of a house can be represented as $\mathbf{p}(\mathrm{z})$, where $\mathrm{z}=\mathrm{z}_{1}, \mathrm{z}_{2}, \ldots, \mathrm{z}_{\mathrm{n}}$ is a vector of structural and neighborhood attributes. The implicit price of attribute $j$ is then given by the partial derivative of $p(z)$ with respect to attribute $j$, or, $p_{j}(z)=\partial p / \partial z_{j}{ }^{11}$ The equilibrium price function, $\mathbf{p}(\mathbf{z})$, is generally thought to be nonlinear because the cost of arbitrage activity that repackages bundles of attributes once a house is built is assumed prohibitive.

\section{B. Geographic Region Considered}

We estimate a hedonic model using properties which sold in or around 20 different Sacramento HPDs over the period 1990-1994. The Sacramento HPDs are highly localized within a three-square mile region, and centered approximately six blocks east of the California State Capitol Building. We defined a region of a two-mile radius from the geographic center of the HPD map.

Property sales data (shown as flags on Map \#1) were obtained from TRW REDI-Property and represent individual single-family residential home sales which took place over the five-year period. ${ }^{12}$ This resulted in a data set of 683 housing sales, of which 58 were located within six HPDs.

\section{Model Specification}

To avoid misspecification biases, we explore a variety of housing influences in the model. These variables can be classified as falling into one of four broad categories: Structural, Neighborhood, Year, and Historic Preservation. A semilog specification is chosen, and the model is specified by equation (1).

\section{$\operatorname{lnRPRICE}=\mathrm{f}$ (Structural, Neighborhood, Year, Historic Preservation)}

All variable definitions, data sources, and descriptive statistics are reported in Table 1. The dependent variable, InRPRICE, is the real sale price of housing (measured in logarithmic form), deflated by the housing component of the CPI. 
MAP \#1

City of Sacramento

Preservation Areas
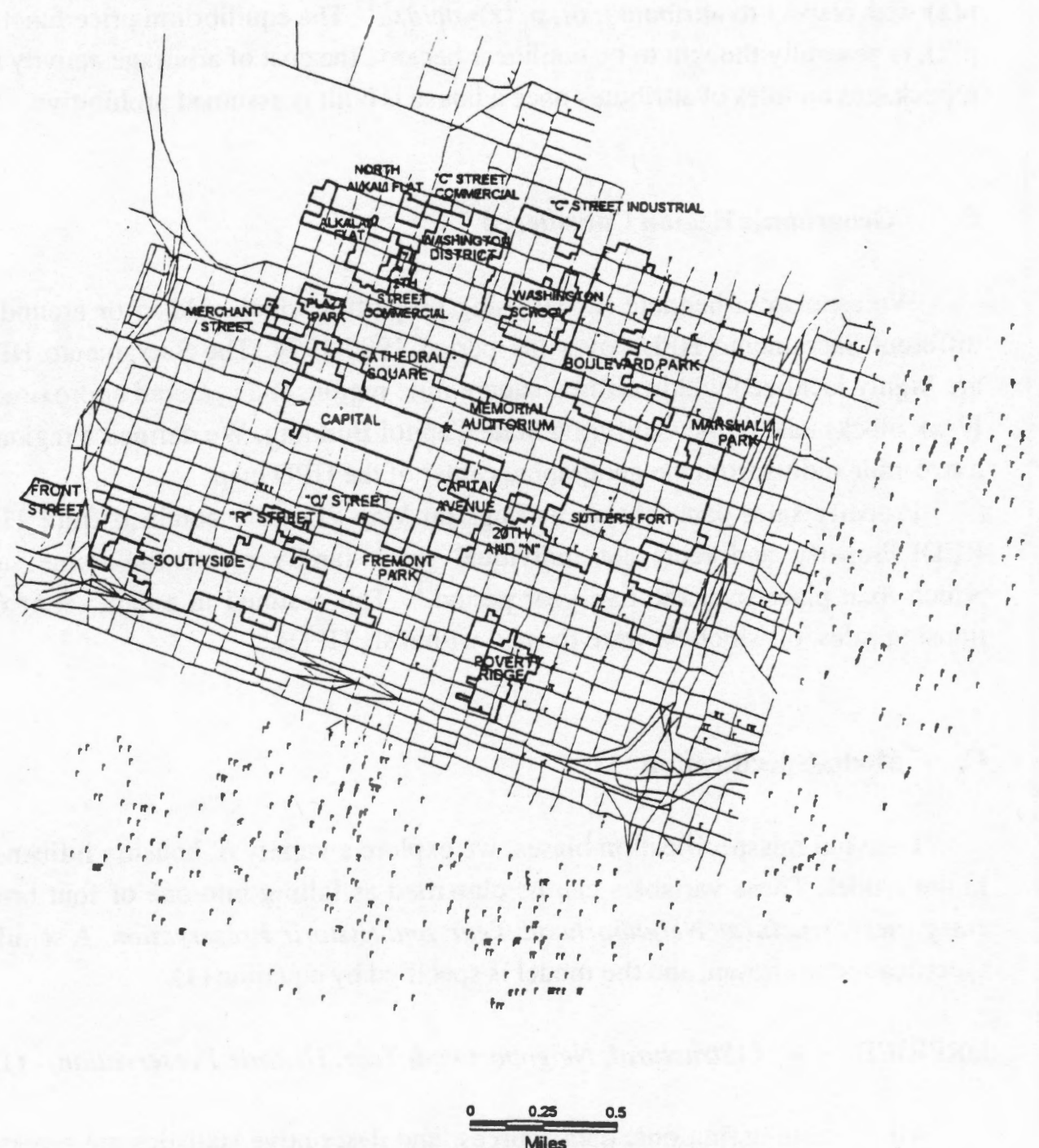
TABLE 1

Variable Name and Definition, Data Source, Predicted Sign

\begin{tabular}{|c|c|c|c|}
\hline Variable Name & $\begin{array}{c}\text { Definition } \\
\text { Mean \& standard deviation in brackets }\end{array}$ & Source & $\begin{array}{l}\text { Predicted } \\
\text { Sign }\end{array}$ \\
\hline \multicolumn{4}{|c|}{ Dependent Variable and Variables in the Structural Category } \\
\hline LRPRICE & $\begin{array}{l}\text { Natural } \log \text { of the real sale price of the } \\
\text { property ( } 1990 \text { dollars) } \\
\text { [mean of RPRICE }=149266.5 \text {, } \\
\sigma=52125.3 \text { ] }\end{array}$ & $\begin{array}{l}\text { TRW nominal } \\
\text { price divided } \\
\text { by the national } \\
\text { CPI for housing. }\end{array}$ & $\begin{array}{c}\text { dependent } \\
\text { variable }\end{array}$ \\
\hline $\begin{array}{l}\text { AGEHOUSE, } \\
\text { AGESQ }\end{array}$ & $\begin{array}{l}\text { Age of house in years; age of house } \\
\text { squared. } \\
\text { [mean of AGEHOUSE }=61.6, \sigma=16.6 \text { ] }\end{array}$ & TRW & ? \\
\hline BEDROOM & $\begin{array}{l}\text { Number of bedrooms in house. } \\
\text { [mean }=2.46, \sigma=0.75 \text { ] }\end{array}$ & TRW & + \\
\hline CNTRLAIR & $\begin{array}{l}1=\text { presence of central air conditioning, } \\
0 \text { otherwise. } \\
\text { [mean }=0.26, \sigma=0.44]\end{array}$ & TRW & + \\
\hline FIREPLCE & $\begin{array}{l}\text { Number of fireplaces in the residence. } \\
\text { [mean }=0.73, \sigma=0.46]\end{array}$ & TRW & + \\
\hline FULLBATH & $\begin{array}{l}\text { Number of full bathrooms in the home. } \\
\text { [mean }=1.26, \sigma=0.48 \text { ] }\end{array}$ & TRW & + \\
\hline HALFBATH & $\begin{array}{l}\text { Number of half bathrooms in the } \\
\text { home. } \\
\text { [mean }=0.11, \sigma=0.31 \text { ] }\end{array}$ & TRW & + \\
\hline NUMSTORY & $\begin{array}{l}\text { Number of stories in the house. } \\
\text { [mean }=1.21, \sigma=0.41]\end{array}$ & TRW & ? \\
\hline \multicolumn{4}{|c|}{ Variables in Historic Preservation District category } \\
\hline & $\begin{array}{l}\text { Dummy variables for six separate } \\
\text { HPD's }\end{array}$ & $\begin{array}{l}\text { Geographic } \\
\text { boundaries }\end{array}$ & ? \\
\hline BLVDPARK & Boulevard Park [mean $=0.03, \sigma=0.18$ ] & \multicolumn{2}{|c|}{ computed from map } \\
\hline POVRTYRDG & Poverty Ridge [mean $=0.001, \sigma=0.03$ ] & \multicolumn{2}{|c|}{ provided by City of } \\
\hline SOUTHSIDE & South Side [mean $=0.02, \sigma=0.12$ ] & \multicolumn{2}{|c|}{ Sacramento Planning } \\
\hline SUTTERSFT & Sutter's Fort [mean $=0.03, \sigma=0.16$ ] & \multirow{2}{*}{\multicolumn{2}{|c|}{ Department }} \\
\hline WASHSCHL & $\begin{array}{l}\text { Washington School } \\
\text { [mean }=0.01, \sigma=0.09\end{array}$ & & \\
\hline WASHDIST & $\begin{array}{l}\text { Washington District } \\
\text { [mean }=0.001, \sigma=0.03 \text { ] }\end{array}$ & & \\
\hline AGE*HPD & $\begin{array}{l}\text { Age of the property interacted } \\
\text { with a dummy variable for historic } \\
\text { preservation district. } \\
\text { [mean }=5.15, \sigma=18.97 \text { ] }\end{array}$ & TRW & ? \\
\hline
\end{tabular}


TABLE 1 (Continued)

Variable Name and Definition, Data Source, Predicted Sign

\begin{tabular}{|c|c|c|c|}
\hline Variable Name & $\begin{array}{c}\text { Definition } \\
\text { Mean \& standard deviation in brackets }\end{array}$ & Source & $\begin{array}{l}\text { Predicted } \\
\text { Sign }\end{array}$ \\
\hline
\end{tabular}

Variables in Historic Preservation District category

\begin{tabular}{|c|c|c|}
\hline ADJHPD & $\begin{array}{l}\text { Dummy variable }=1 \text { if the property } \\
\text { is across the street from an HPD, } \\
0=\text { otherwise. [mean }=0.01, \sigma=0.12 \text { ] }\end{array}$ & Computed \\
\hline NEARHPD & $\begin{array}{l}\text { Dummy variable }=1 \text { if property is } \\
\text { within } 1 \text { block of HPD, } 0=\text { otherwise. } \\
\text { [mean }=0.01, \sigma=0.09 \text { ] }\end{array}$ & Computed \\
\hline \multicolumn{3}{|c|}{ Variables in the Neighborhood Category } \\
\hline OZONE & $\begin{array}{l}\text { Distance weighted value of the } \\
\text { nearest ozone monitor, computed } \\
\text { as the ozone concentration divided } \\
\text { by the distance of the monitor to } \\
\text { the property. [mean }=7.48, \sigma=12.76 \text { ] }\end{array}$ & $\begin{array}{l}\text { EPA-AIRS AQS } \\
\text { database }\end{array}$ \\
\hline INTERSTATE & $\begin{array}{l}\text { 1=interstate highway within } \\
0.25 \text { miles of property. } 0=\text { otherwise. } \\
\text { [mean }=0.26, \sigma=0.44 \text { ] }\end{array}$ & $\begin{array}{l}\text { MapInfo } \\
\text { computed }\end{array}$ \\
\hline RAILROAD & $\begin{array}{l}1=\text { railroad tracks within } 0.25 \text { miles } \\
\text { of property. } 0=\text { otherwise. } \\
\text { [mean }=0.35, \sigma=0.48 \text { ] }\end{array}$ & $\begin{array}{l}\text { MapInfo } \\
\text { computed }\end{array}$ \\
\hline SUPERFUND & $\begin{array}{l}\text { Number of sites which are on the } \\
\text { National Priorities List (i.e., Super- } \\
\text { fund site), within } 5 \text { miles of the } \\
\text { property. } \\
\text { [mean }=1.33, \sigma=0.47 \text { ] }\end{array}$ & Landview II \\
\hline \%HISPAN & $\begin{array}{l}\text { Percent of the census tract population } \\
\text { that is of hispanic origin. } \\
\text { [mean }=13.71, \sigma=6.92]\end{array}$ & Census STF-3A \\
\hline \%BLACK & $\begin{array}{l}\text { Percent of the census tract population } \\
\text { that is black. } \\
\text { [mean }=7.83, \sigma=8.19 \text { ] }\end{array}$ & Census STF-3A \\
\hline \%ASIAN & $\begin{array}{l}\text { Percent of the census tract population } \\
\text { that is asian or pacific islander. } \\
\text { [mean }=9.38, \sigma=11.07 \text { ] }\end{array}$ & Census STF-3A \\
\hline
\end{tabular}


TABLE 1 (Continued)

Variable Name and Definition, Data Source, Predicted Sign

\begin{tabular}{|c|c|c|c|}
\hline Variable Name & $\begin{array}{c}\text { Definition } \\
\text { Mean \& standard deviation in brackets }\end{array}$ & Source & $\begin{array}{l}\text { Predicted } \\
\text { Sign }\end{array}$ \\
\hline \multicolumn{4}{|c|}{ Variables in the Neighborhood Category } \\
\hline \%OWNOCC & $\begin{array}{l}\text { Percent of the census tract occupied } \\
\text { housing units that are owner occupied. } \\
\text { [mean=50.61, } \sigma=23.31 \text { ] }\end{array}$ & Census STF-3A & + \\
\hline \%OCCUNIT & $\begin{array}{l}\text { Percent of the census tract housing } \\
\text { units that are occupied. } \\
\text { [mean=93.94, } \sigma=2.85 \text { ] }\end{array}$ & Census STF-3A & + \\
\hline COMMUTE & $\begin{array}{l}\text { Average travel time of households } \\
\text { living in that census tract. } \\
\text { [mean=18.75, } \sigma=2.30 \text { ] }\end{array}$ & Census STF-3A & - \\
\hline TAXRATE & $\begin{array}{l}1994 \text { tax payment divided by } 1994 \\
\text { assessed valuation. } \\
\text { [mean }=0.01, \sigma=0.001 \text { ] }\end{array}$ & TRW & - \\
\hline TSRATIO & $\begin{array}{l}\text { Teacher-student ratio for public } \\
\text { school district in which the property } \\
\text { resides. } \\
\text { [mean }=0.04, \sigma=0.001 \text { ] }\end{array}$ & $\begin{array}{l}\text { California } \\
\text { Department of } \\
\text { Education }\end{array}$ & + \\
\hline WATER & $\begin{array}{l}1=\text { lake, river or stream within } 0.25 \\
\text { miles of property, } 0=\text { otherwise. } \\
{[\text { mean }=0.04, \sigma=0.19]}\end{array}$ & $\begin{array}{l}\text { MapInfo } \\
\text { computed. }\end{array}$ & + \\
\hline $\begin{array}{l}\text { Year dummy } \\
\text { variables }\end{array}$ & 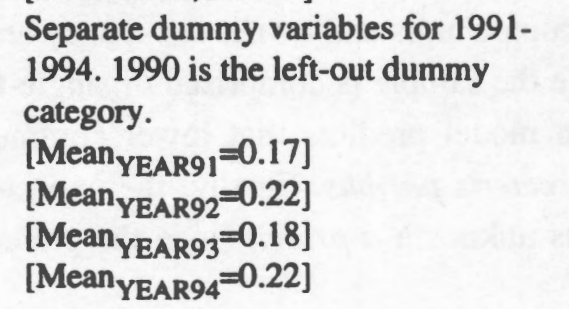 & $\begin{array}{l}\text { TRW } \\
\text { REDI-Property }\end{array}$ & ? \\
\hline
\end{tabular}

\section{Structural Variables}

The first category of variables, Structural, represents structural features of the house. Among the variables contained in this category are the number of bedrooms (BEDROOM), full and half baths (FULLBATH, HALFBATH), the presence of central air conditioning (CENTRAL), the presence of a fireplace (FIREPLCE), the age of the structure in linear and quadratic form (AGEHOUSE, AGESQ) and the number of stories in the house (NUMSTORY). Additional attributes should serve to increase the value of the property, and thus all structural characteristics with the exception of AGEHOUSE, AGESQ, and NUMSTORY 
are expected to have positive coefficients in the hedonic regression. The influence of NUMSTORY is ambiguous. Some households (e.g., the elderly) may prefer single-story properties, whereas others may prefer the extra space provided by multistory buildings located on relatively small properties. In addition, maintenance costs may rise with the age of the structure. However, it is also possible that some qualitative features of homes (e.g., hardwood floors, crown molding, etc.) may be found only on older properties. To allow for nonmonotonicity in the hedonic housing price function, we include age in quadratic form.

\section{Neighborhood Variables}

Since the TRW-REDI Property data comes geocoded, we were able to match a wide range of neighborhood characteristics to each property. The MapInfo PCbased GIS package is used to map each variable to the associated property. Each property is matched to a census tract, and the characteristics of that tract are then assigned to the property. Among the tract characteristics included are the percent of the houses that are occupied (\%OCCUNITS); the percent of the occupied units that are owner occupied (\%OWNOCC); and the racial and ethnic mix of the tract (\%BLACK, \%ASIAN, and \%HISPANIC). Finally, proximity to the workplace is measured by the average commute time for the census tract. While it would be desirable to have these measures defined for each year of the sample, 1990 values must be used, since they are the most recently available data. Neighborhoods with relatively higher rates of occupied units and owner occupancy are expected to exhibit higher sale prices, since the sample is comprised of single-family homes. In addition, the urban location model predicts that lower commute times should result in higher sale prices, ceteris paribus. Finally, the expected impact of the racial and ethnic variables is unknown a priori, since the preferences of buyers are unknown.

We also use GIS tools to determine how close each property is to various types of noxious activity. Specifically, we examine noxious activity related to proximity to interstate highways (INTRSTATE) and railroads (RAILROAD), as well as air quality in the neighborhood (OZONE). Since ozone monitors are not uniformly dispersed throughout metropolitan areas, but rather are placed in areas which are more likely to have higher ozone levels, we construct a distanceweighted value for ozone which is the reading from the closest monitor, divided by the distance from that monitor. Proximity to hazardous materials is proxied by the number of Superfund sites that are within a five-mile radius of each property (SUPERFUND). Overall, one would expect that proximity to noxious activity reduces the sale price of the property. 
We include proximity to lakes, rivers and streams (WATER) to proxy access to aesthetic and recreational amenities. In addition, we include the teacher-student ratio (TSRATIO) of the public school district in which the property is located to capture school quality, and we also include the property tax rate for the property (TAXRATE) to measure the local property tax burden. Amenities and school quality should enhance property values, whereas a high tax burden should have the opposite effect.

\section{Year Dummy Variables}

Since these data are defined over a five-year period (1990-1994), we include dummy variables for the year in which the property sold. The left-out dummy category is 1990 . We include these variables to control for the influence of disequilibrium in the housing market as a result of the substantial decline in property values over the 1990s. Although more precise controls would be desirable (e.g., annual net migration rates within specific neighborhoods) such data are, to our knowledge, unavailable.

\section{Historic Preservation District Variables}

To model the influence of HPDs, we include dummy variables for each of the districts in which properties sold over the period. Our sample contained sales in six of the 20 HPDs in the Sacramento metropolitan area. Of these 58 properties, most were contained within the three largest geographic HPDs: Boulevard Park (23 properties), Sutter's Fort (17 properties), and Southside (10 properties). While the age of the house has no a priori expected sign in this model, it is possible that its influence within HPDs differs from its influence outside those areas. To allow for that possibility, we interact AGEHOUSE with a dummy variable which takes on a unit value for the 58 properties sold within HPDs, and a zero otherwise. Finally, HPDs may affect nearby properties outside district boundaries. To test for these possible spillovers, we include ADJHPD, which equals one for properties across the street from an HPD boundary, and NEARHPD, which equals one for properties within a block of the boundary. Ten properties were across the street, and an additional six were within one block of an HPD.

\section{EMPIRICAL FINDINGS}

White's test for heteroskedasticity reveals a nonhomoskedastic error structure, and we correct for this problem using White's correction technique (White 
TABLE 2

Hedonic Regression Results

Dependent Variable: Log of Real Home Sale Price (Period=1990-1994)

\begin{tabular}{|c|c|c|c|c|}
\hline Variable & Coefficient & S.E. & t-Statistic & Prob. \\
\hline INTERCEPT & 8.681159 & 1.031172 & 8.418733 & 0.0000 \\
\hline \multicolumn{5}{|c|}{ Structural Characteristic Variables } \\
\hline BEDROOM & 0.082218 & 0.019027 & 4.321168 & 0.0000 \\
\hline FULLBATH & 0.076250 & 0.035658 & 2.138389 & 0.0329 \\
\hline HALFBATH & 0.157284 & 0.031565 & 4.982838 & 0.0000 \\
\hline CNTRLAIR & 0.059717 & 0.022163 & 2.694501 & 0.0072 \\
\hline FIREPLCE & 0.215108 & 0.028292 & 7.603255 & 0.0000 \\
\hline NUMSTORY & 0.109488 & 0.036711 & 2.982461 & 0.0030 \\
\hline AGEHOUSE & 0.007181 & 0.003437 & 2.089391 & 0.0371 \\
\hline AGESQ & $-5.83 E-05$ & 3.70E-05 & -1.576453 & 0.1154 \\
\hline \multicolumn{5}{|c|}{ Neighborhood Characteristic Variables } \\
\hline OZONE & -0.000496 & 0.000635 & -0.781422 & 0.4348 \\
\hline INTRSTAT & -0.100843 & 0.025923 & -3.890159 & 0.0001 \\
\hline RAILROAD & -0.089504 & 0.020714 & -4.320977 & 0.0000 \\
\hline SUPERFUND & -0.042311 & 0.024404 & -1.733750 & 0.0834 \\
\hline WATER & 0.042788 & 0.043423 & $0: 985379$ & 0.3248 \\
\hline \%OCCUN & 0.019060 & 0.008533 & 2.233720 & 0.0258 \\
\hline \%OWNOCC & 0.001058 & 0.000856 & 1.236928 & 0.2166 \\
\hline COMMUTE & -0.013541 & 0.010071 & -1.344544 & 0.1792 \\
\hline \%ASIAN & -0.005023 & 0.001729 & -2.905784 & 0.0038 \\
\hline \%BLACK & -0.000818 & 0.003192 & -0.256100 & 0.7980 \\
\hline \%HISPANIC & -0.002118 & 0.003832 & -0.552678 & 0.5807 \\
\hline TSRATIO & 28.86199 & 6.406453 & 4.505144 & 0.0000 \\
\hline TAXRATE & -13.96402 & 19.90939 & -0.701379 & 0.4833 \\
\hline \multicolumn{5}{|c|}{ Year Dummy Variables } \\
\hline YEAR91 & -0.039166 & 0.032893 & -1.190708 & 0.2342 \\
\hline YEAR92 & -0.038116 & 0.036828 & -1.034977 & 0.3011 \\
\hline YEAR93 & -0.114392 & 0.034702 & -3.296444 & 0.0010 \\
\hline YEAR94 & -0.207670 & 0.041824 & -4.965326 & 0.0000 \\
\hline \multicolumn{5}{|c|}{ Historic Preservation District Variables } \\
\hline BLVDPARK & 0.356550 & 0.126029 & 2.829117 & 0.0048 \\
\hline POVERTYRDG & 0.315522 & 0.169130 & 1.865554 & 0.0626 \\
\hline SOUTHSIDE & 0.207264 & 0.146818 & 1.411705 & 0.1585 \\
\hline SUTTERSFT & 0.034620 & 0.139371 & 0.248400 & 0.8039 \\
\hline WASHDIST & 0.283514 & 0.096927 & 2.925021 & 0.0036 \\
\hline WASHSCHL & 0.314744 & 0.130942 & 2.403699 & 0.0165 \\
\hline AGEHPD & -0.003020 & 0.001751 & -1.724637 & 0.0851 \\
\hline ADJHPD & -0.200084 & 0.077677 & -2.575841 & 0.0102 \\
\hline NEARHPD & -0.084460 & 0.125908 & -0.670801 & 0.5026 \\
\hline
\end{tabular}

$\mathrm{R}^{2}$ ADJUSTED $=0.539$ 
1980). The hedonic model provides a good fit to the data, explaining 53.9 percent of the variation in the log of the real sale price. (see Table 2).

All of the variables within the Structural category are statistically significant with the a priori expected sign when there was a sign expectation. Multistory homes sold for more than single-story properties, possibly reflecting a desire for extra living space on relatively expensive, and thus smaller, plots of land. In addition, AGEHOUSE increases housing prices, but at a decreasing rate. ${ }^{13}$ Note that the quadratic term is not quite significant at the $\mathbf{9 5}$ percent level of confidence. AGESQ is retained, however, because dropping it resulted in an insignificant coefficient on AGEHOUSE, and a worse overall fit.

A few points also need to be made regarding the magnitudes of several coefficients. First, note that the largest coefficients are on HALFBATH and FIREPLCE. While it is not surprising that these variables have positive coefficients, one would not expect HALFBATH to have a higher coefficient than FULLBATH, nor would a fireplace be expected to add nearly three times the value of an additional bedroom. We suspect that both of these variables are actually capturing qualitative aspects of the property that are unmeasured in our specification.

Most of the neighborhood characteristics are correctly signed (when a sign expectation exists) and many are statistically significant. For example, properties which are within 0.25 miles of an interstate highway reduce property sales prices by 10 percent, whereas those within 0.25 miles of a railroad experience real price reductions of 9 percent. In contrast, an additional Superfund site within 5 miles of the property diminishes the sale price by about 4.2 percent. Each additional percentage increase in occupied units in the census tract increases the sale price of a property by nearly 2 percent. Higher owner occupancy rates increase the sale price of the property, as does a shorter commute time. Indeed, a ten-minute reduction in the average commute enhances the sale price by about 14 percent. While neither \%OWNOCC nor COMMUTE is statistically significant at the 95 percent level of confidence, both have t-statistics exceeding 1.20. High concentrations of Asian populations in the census tract significantly reduced real sale prices, although black and hispanic populations do not have a significant impact on prices. Interestingly, when the \%OCCUNIT variable is dropped from the model, \%BLACK becomes negative and significant. This suggests that one should use caution in interpreting this variable in other regression models, as it may well capture other influences in addition to the impact of racial mix. Finally, a high teacher-student ratio significantly increases the sale price of properties within that district.

The dummy variables for the year in which the sale took place are all negative. The coefficients on YEAR93 and YEAR94 are statistically significant, sug- 
gesting that sale prices were, respectively, 11.8 percent and 21.0 percent lower than they were in 1990. The magnitude of these coefficients is not surprising, given the economic decline experienced in the California housing market in the 1990s. Given the size of the standard errors, it makes sense that significant differences from 1990 show up only as the real estate market continued to decline in 1993 and 1994.

Finally, the coefficients on historic preservation districts reveals some interesting findings. First, all HPD dummy variables have positive coefficients, which suggests that other things being equal, a house located in an historic preservation district sells for a premium over similar houses outside the district. Of the six different districts evaluated in this hedonic model, three have positive and significant coefficients, and one is significant at the 90 percent level of confidence. ${ }^{14}$ As noted in the discussion of the structural characteristics, the interaction term between AGEHOUSE and HPD is negative and nearly significant. This suggests that the effect of age is to depress the housing price premium associated with HPDs. However, for the five HPDs which have the strongest impact (and highest t-statistics), the negative effect of age does not overwhelm the HPD effect until the property approaches 100 years. To evaluate the impact of the interaction between HPD and AGEHOUSE, we consider the housing price premium evaluated at the mean, and at one standard deviation above and below the mean. These findings are reported in Table 3. With the exception of Southside, the housing price premium varied between 10.02 percent and 17.32 percent at the mean age of 60.7 years. Note that the Southside premium is only 2.4 percent, although its p-value is 0.159 . The premium varied by approximately 9 percent at one standard deviation above and below the mean age of the house.

We find no evidence of positive spillovers from properties which are in the vicinity of HPDs. In fact, the coefficient on ADJHPD suggests that HPDs lower the prices of adjacent properties by approximately 20 percent. This latter finding is consistent with Coffin's (1989) suggestion that an increase in demand for housing within the HPD may cause a decrease in demand elsewhere in the metropolitan housing market. If buyers have decided on a general location within the city and are otherwise indifferent between houses on either side of the boundary, the HPD designation may actually decrease demand enough to significantly depress prices right outside the district. ${ }^{15}$

\section{CONCLUSIONS AND POLICY IMPLICATIONS}

The results suggest that HPDs exert a net positive influence on housing prices. This indicates that the effect of positive 'authenticity' and 'upkeep' exter- 
TABLE 3

Real Housing Price Premium (\%) for HPD Residence by Age of Structure (In percent)

\begin{tabular}{lccc}
\hline \hline District & $\begin{array}{c}\text { Mean Age }-1 * \sigma \\
(31.0 \text { years })\end{array}$ & $\begin{array}{c}\text { Mean Age } \\
(60.7 \text { years) }\end{array}$ & $\begin{array}{c}\text { Mean Age }+1 * \sigma \\
(90.4 \text { years) }\end{array}$ \\
\hline Boulevard Park & 26.29 & 17.32 & 8.35 \\
Poverty Ridge & 22.19 & 13.22 & 4.25 \\
Southside & 11.36 & 2.40 & -6.57 \\
Washington District & 18.99 & 10.02 & 1.05 \\
Washington School & 22.11 & 13.14 & 4.17 \\
\hline
\end{tabular}

nalities outweigh the higher costs, due to onerous rules, of property improvement within an HPD. The combined effect of these externalities yields sale prices up to 17.32 percent higher for an average-aged house within a preservation area. Improvements done in these areas thus result in maintaining the 'look' of an older structure and thus the 'character' of the neighborhood. With the exception of SUTTERSFT, there is little evidence to suggest that the permit application process is burdensome enough to mitigate the positive aspects of location within a historical preservation area.

Zoning laws and restrictive covenants have had success in mitigating externalities from the close proximity of conflicting commercial, industrial, and residential land uses (Moore 1978; Kendig 1980, 1987; Hughes and Turnbull 1996). HPD creation may be the next step in the evolution of land use regulations as greater numbers of metropolitan areas search for ways to renew interest in inner-city residential locations. Our results suggest this may be a promising policy to pursue. By making the housing stock more valuable and attractive to middleand upper-middle class buyers, HPDs could increase the tax base at very little public cost. Conversely, lower property values increase the likelihood of housing abandonment (Mills and Hamilton 1994). To the extent that spending for police and fire protection are positive functions of abandonment (Sternlieb and Burchell 1973), HPDs could also conceivably lower public spending. ${ }^{16}$

We close with two important qualifications. The success of an HPD policy is likely predicated on characteristics of the neighborhood. For example, Berry (1985) has argued that successful gentrification typically occurs in neighborhoods with older Victorian housing, well-denoted borders, and favorable access to the $\mathrm{CBD}$; and in cities with an economically vibrant $\mathrm{CBD}$ and favorable access to the CBD. While we do not have specific information on the style of housing sold in the HPDs, the neighborhoods are centrally located and the housing has an average age of nearly 61 years. Furthermore, while unemployment has been relatively high in Sacramento during the 1990 s, the CBD is dominated by state government 
employment, which tends to be less variable than private sector employment. Thus, the neighborhoods examined in this paper appear to have some of the features which lead to successful revitalization. Second, we emphasize that our results apply only to Sacramento. HPD rules surely vary from city to city, and it is reasonable to believe that different rules will have different effects on housing price. A logical extension would be to contrast these results with comparable metropolitan areas that also contain HPDs. With sufficient data, one may be able to identify specific rules that have the largest impact.

\section{ENDNOTES}

1. The authors would like to thank Lisa Michelbrink for her assistance in the use of GIS software. We also thank Don English, two anonymous referees, and participants in the Economics Department Colloquium at University of the Pacific for insightful comments on an earlier draft. The usual disclaimers apply.

2. The Tax Recovery Act of $\mathbf{1 9 8 1}$ provided briefly for a federal tax credit for historic preservation.

3. The Sacramento Preservation Board defines a Preservation Area as an area or place having a special architectural character or historic interest, comprised of contiguous sites that reflect a distinct and unified character.

4. The Listed Structures Plan explains policies and benefits to be derived from preservation, identifies significant pre-1920 individual structures, and outlines the measures necessary to protect and preserve these structures. The Preservation Area Plan establishes the Preservation Board's responsibility for reviewing all rehabilitation, relocation, demolition, and new construction within preservation areas.

5. City of Sacramento, Preservation Area Plan, Design Guidelines, Residential and Nonresidential Structures.

6. City of Sacramento Preservation Board, Listed Structures Plan, Residential Buildings, p.4.

7. Ibid.

8. Ibid.

9. Ibid., pp. 9-10.

10. In light of the aforementioned definition of a Preservation Area, one might argue that higher values due to special character or historic interest may dictate HPD boundaries, rather than the HPD designation causing higher values. In that case, HPD designation would be endogenous. However, we use data compiled 15 years after the current boundaries were established. Hence the HPD designation is exogenous to each individual property. 
11. Rosen (1974) shows that this implicit price does not represent an individual's willingness to pay for the attribute. The implicit price can be used, however, to derive the demand for an attribute in a second-stage estimation process. Brown and Rosen (1982), Diamond and Smith (1985), Epple (1987), Bartik (1987), and others, however, have noted the existence of identification problems that make estimation of these demand functions difficult. Our work need only focus on the single stage model.

12. TRW REDI-Property obtained the data from yearly county tax rolls. These data were then merged with weekly new deed reports from the county recorder's office. Additional information (e.g., for structural characteristics) about the properties is obtained from various appraisal groups because not all counties obtain information at the same level of detail. In California there are two situations which would result in a property sale not being included in the TRW REDI data set: (1) A specific request for nondisclosure by the owner (usually a wellknown individual who would not want the public to know the price of the property) and; (2) The sales tax information (from which the price is calculated) is not located on the first page of the recorder's document, which is the source of information for TRW REDI-Property. The first situation is likely to systematically undercount high-priced properties. However, given the geographic location of this housing market, this undercount is not likely to bias our findings. Furthermore, TRW has indicated that the second situation is unlikely to introduce systematic bias into the sample. TRW estimates that 46 percent of the approximately 6 million properties had sales tax data.

13. Recall that AGEHOUSE is also interacted with a dummy variable for HPD. That coefficient is negative, but smaller in absolute value than the positive coefficient on AGEHOUSE. This implies that, ceteris paribus, the value of homes rises with age until 61.6 years, after which it declines. For homes selling within HPDs, the sale price maximizing age is only 35.7 years.

14. The federal tax provisions mentioned earlier effectively subsidize improvements, and their effects are presumably capitalized into sales prices. This may help explain the magnitude of the four significant HPD coefficients. Because our data do not contain information about individual tax liability or amounts spent on improvements, we cannot determine what proportion of the coefficients may be due to this subsidy.

15. Median household income of the census tract was added to the equation to see if the explanatory power of the other demographic variables improves. The statistical significance of all the attributes in the equation does not change, nor is there any appreciable change in the magnitudes of the coefficients. 
16. HPD creation may require the local government to provide more and better public services (e.g., police protection and lighting). This issue, while important for policy purposes, is not addressed here.

\section{REFERENCES}

Bartik, Timothy J. "The Estimation of Demand Parameters in Hedonic Price Models." Journal of Political Economy 95 (1987): 81-88.

Bender, Bruce and Hae-Shin Hwang. "Hedonic Price Indices and Secondary Employment Centers." Journal of Urban Economics 17 (1985): 90-107.

Berry, Brian J.L. "Islands of Renewal in Seas of Decay." In The New Urban Reality, edited by Paul E. Peterson. Washington D.C.: The Brookings Institute, 1985.

Brown, James N., and Harvey Rosen. "On the Estimation of Structural Hedonic Price Models." Econometrica 50 (1982): 765-68.

City of Sacramento. Preservation Area Plan, Design Guidelines, Residential and Nonresidential Structures, 1975.

City of Sacramento Preservation Board. Listed Structures Plan: Residential Buildings, 1976.

Clark, David E., and James C. Cosgrove. "Hedonic Prices, Identification, and the Demand for Public Safety." Journal of Regional Science 30 (1990): 105-21.

Coffin, Donald A. "The Impact of Historic Districts on Residential Property Values." Eastern Economic Journal 15 (1989): 221-28.

Delafons, John. Land Use Controls in the United States. Cambridge, MA: MIT Press, 1969.

Diamond, Douglas B., and Barton A. Smith. "Simultaneity in the Market for Housing Characteristics." Journal of Urban Economics 17 (1985): 280-92.

Epple, Dennis. "Hedonic Prices and Implicit Markets: Estimating Demand and Supply Functions for Differentiated Products." Journal of Political Economy 95 (1987): 59-80.

Fischel, William. The Economics of Zoning Laws. Baltimore, MD: Johns Hopkins University Press, 1985.

Freeman, A. Myrick III. The Benefits of Environmental Improvement: Theory and Practice. Baltimore, MD: Johns Hopkins University Press, 1979.

Garrod, K.G., H. Willis, H. Bjarnadottir, and P. Cockbain. "Using the Contingent Valuation Method in the Economic Appraisal of the Renovation of Historic Buildings." In forthcoming book, Evaluation in the Built Environment for Sustainability. London: E\&FN Spon, Chapman and Hall, 1997. 
Harrison, David, Jr., and Daniel L. Rubinfeld. "Hedonic Housing Prices and the Demand For Clean Air." Journal of Environmental Economics and Management 5 (1978): 81-102.

Herrin, William E., and Clifford R. Kern. "Testing the Standard Urban Model of Residential Choice: An Implicit Markets Approach." Journal of Urban Economics. 31 (1992): 145-63.

Hughes, William T., and Geoffrey K. Turnbull. "Uncertain Neighborhood Effects and Restrictive Covenants." Journal of Urban Economics 39 (1996): 160172.

Kendig, Lane. Performance Zoning. Chicago, IL: American Planning Association, 1980.

New Standards for Nonresidential Uses. Chicago, IL: Report 405, American Society of Planning Officials, 1987.

Kern, Clifford R., and Larry Lichtenstein. "The Cost of Quality in Existing Housing: Estimates From an Implicit Markets Model." Journal of Urban Economics 22 (1987): 324-39.

Lancaster, Kelvin J. "A New Approach to Consumer Theory." Journal of Political Economy 74 (1966): 132-57.

Linneman, Peter. "Some Empirical Results on the Nature of the Hedonic Price Function for the Urban Housing Market." Journal of Urban Economics 8 (1980): 47-68.

Mills, Edwin. "Economic Analysis of Urban Land-Use Controls." in Current Issues in Urban Economics, edited by Peter Mieszkowski and Mahlon Straszheim. Baltimore, MD: Johns Hopkins University Press, 1979.

Mills, Edwin, and Bruce W. Hamilton. Urban Economics, 5th ed. New York, NY: Harper Collins College Publishers, 1994.

Moore, Terry. "Why Allow Planners to Plan?" American Institute of Planners Journal 44 (1978): 387-98.

O'Sullivan, Arthur. Urban Economics, 3rd ed. Chicago, IL: Irwin Publishers, 1996.

Ridker, R. G., and J. A. Henning. "The Determinants of Residential Property Values with Special Reference to Air Pollution." Review of Economics and Statistics 46 (1967): 246-57.

Rosen, Sherwin. "Hedonic Prices and Implicit Markets: Product Differentiation in Pure Competition." Journal of Political Economy 82 (1974): 132-57.

Sternlieb, George, and Robert W. Burchell. The Tenement Landlord Revisited. New Brunswick, NJ: Rutgers University Press, 1973.

Stull, William J., and Judith C. Stull. "Capitalization of Local Income Taxes." Journal of Urban Economics 29 (1991): 182-90. 
Thaler, Richard. "A Note on the Value of Crime Control: Evidence from the Property Market." Journal of Urban Economics 5 (1978): 137-45.

White, Halbert. "A Heteroscedasticity-Consistent Covariance Matrix Estimator and a Direct Test for Heteroscedasticity." Econometrica 48 (1980): 817-38. 